\title{
HIV-1 Group O Antibody Measurement
}

National Cancer Institute

\section{Source}

National Cancer Institute. HIV-1 Group O Antibody Measurement. NCI Thesaurus. Code C92264.

The determination of the amount of HIV-1 group $\mathrm{O}$ antibody present in a sample. 